\title{
Pendapatan Usahatani Kelapa Sawit Petani Plasma dan Petani Swadaya di Kecamatan Luhak Nan Duo Kabupaten Pasaman Barat
}

\section{Oil Palm Farming Income of Smallholders and Independent Smallholders in Luhak Nan Duo Sub-District, West Pasaman District}

\author{
Oleh: \\ Karina Ratna Sari' ${ }^{1}$, Hasnah ${ }^{2}$, Cipta Budiman ${ }^{2}$ \\ ${ }^{1}$ Mahasiswa Program Studi Agribisnis Fakultas Pertanian Universitas Andalas, Padang \\ ${ }^{2}$ Staff Pengajar Program Studi Agribisnis Fakultas Pertanian Universitas Andalas, Padang \\ *email: lamtiarsilahi0609@gmail.com
}

Received September 29, 2020; Revised November 24, 2020; Accepted December 12, 2020

\begin{abstract}
ABSTRAK
Penelitian ini bertujuan untuk mengetahui mendeskripsikan profil usaha perkebunan kelapa sawit petani plsama dengan petani swadaya dan menganalisis perbandingan pendapatan dan keuntungan usahatani kelapa sawit antara petani plasma dengan petani swadaya di Kecamatan Luhak Nan Duo Kabupaten Pasaman Barat. Metode penelitian yang digunakan adalah metode survey. Pengambilan data dilakukan melalui wawancara dan pengisian kuisioner. Metode survey adalah penyelidikan yang diadakan untuk memperoleh fakta-fakta dari gejala-gejala yang ada dan mencari keterangan-keterangan secara faktual,baik tentang insititusi soaial. Keuntungan merupakan selisih antara penerima dengan biaya yang dibayarkan dan biaya yang diperhitungkan dalam proses produksi. Rata-rata penerimaan yang diterima petani plasma perluas lahan adalah Rp. 6,412,800.00. Penerimaan petani swadaya adalah sebesar Rp. $13,000,985.22$ per hektar.
\end{abstract}

Kata kunci: kelapa sawit, usahatani, keuntunngan, petani plasma

\begin{abstract}
This study aims to describe the business profile of Plasma farmers and independent smallholders and to analyze the comparison of income and profits of oil palm farming between plasma farmers and independent smallholders in Luhak Nan Duo District, West Pasaman Regency. The research method used is a survey method. Data were collected through interviews and questionnaires. The survey method is an investigation conducted to obtain facts from existing symptoms and to seek factual information, both about social institutions. Profit is the difference between the recipient and the costs paid and the costs calculated in the production process. The average revenue received by the plasma farmers for land expansion is Rp. 6,412,800.00. Independent farmer revenue is $R p .13,000,985.22$ per hectare.
\end{abstract}

Keywords: oil palm, farming, profit, plasma farmers

\section{PENDAHULUAN}

Kelapa sawit merupakan salah satu komoditas tanaman perkebunan yang tumbuh di Indonesia. Tanaman perkebunan ini mampu tumbuh dan berkembang dengan baik di wilayah Indonesia dan produk olahannya yaitu minyak sawit menjadi salah satu produk yang handal. Konsumsi minyak sawit dunia yang amat besar tidak mungkin terpenuhi oleh Malaysia, Nigeria dan Pantai Gading sebagai produsen utama. Beberapa 
pengkaji sosial-ekonomi komoditas perkebunan bahkan menyatakan optimasi lain, keragaman kegunaan minyak sawit sebagai bahan baku industri pangan dan non pangan memungkinkan prospeknya lebih cerah dibandingkan dengan kopi dan karet olahan (Adiwilaga, 1992).

Kelapa sawit merupakan salah satu sumber devisa negara sehingga luas perkebunan kelapa sawit di Indonesia mengalami peningkatan tiap tahunnya. Luas perkebunan kelapa sawit berdasarkan status penguasaan dibedakan menjadi 3 yaitu: perkebunan besar negara,perkebunan besar swasta, dan perkebunan rakyat. Luas area perkebunan kelapa sawit di Indonesia berdasarkan status penguasaannya pada tahun 2016 luas area perkebunan besar swasta, dan perkebunan rakyat. Luas areal perkebunan kelapa sawit di Indonesia berdasarkan status penguasaannya pada tahun 2016 luas area perkebunan besar Negara ialah $707.428 \mathrm{Ha}$ berkurang pada tahun 2017 menjadi 638.143 Ha. Sedangkan untuk perkebunan besar swasta dan perkebunan rakyat luas perkebunan kelapa sawit mengalami peningkatan dari tahun 2016 ke tahun 2017. Untuk perkebunan besar swasta pada tahun 2016 seluas 5.754.719 Ha dan bertambah pada tahun 2017 menjadi 6.047.066 Ha. Untuk perkebunan rakyat pada tahun 2016 perkebunan kelapa sawit seluas 4.739.318 Ha dan meningkat pada tahun 2017 menjadi 5.613.241 Ha. Dapat dilihat bahwa perkebunan sawit di Indonesia paling banyak dimiliki oleh perkebunan besar swasta dan perkebunan rakyat (BPS, 2017).

Komoditi kelapa sawit mempunyai peranan yang sangat penting dalam perekonomian Sumatera Barat terutama perolehan devisa dan penyerapan tenaga kerja sejak tahun 1980-an. Komoditi ini telah menjadi sumber pendapatan lebih dari 185.938 rumah tangga petani di Sumatera Barat dan menghasilkan devisa sebesar 1,2 milyar USD pada tahun 2015 bagi Sumatera Barat (Kementerian Pertanian, 2016). Walaupun usahatani kelapa sawit telah ada sejak tahun 1970-an, namun mulai berkembang di Sumatera Barat sejak tahun 1984. Kemudian sejak tahun 1990 berkembang secara besar-besaran. Perkembangan Luas Lahan Perkebunan Kelapa Sawit di Sumatera Barat Periode 2013-2015.

Pembangunan perkebunan kelapa sawit memiliki dampak ganda terhadap ekonomi wilayah, terutama sekali dalam menciptakan kesempatan dan peluang kerja. Pembangunan perkebunan kelapa sawit ini telah memberikan tetesan manfaat, sehingga dapat memperluas daya penyebaran pada masyarakat sekitarnya. Semakin berkembangnya perkebunan kelapa sawit, semakin terasa dampaknya terhadap tenaga kerja yang bekerja pada sektor perkebunan dan sektor turunannya. Dampak tersebut dapat dilihat dari peningkatan pendapatan masyarakat petani, sehingga meningkatnya daya beli masyarakat pedesaan, baik untuk kebutuhan primer maupun kebutuhan sekunder (Defidelwina, 2013, Zakaria et al. 2020).

Masyarakat Pasaman Barat khususnya di Kecamatan Luhak Nan Duo mayoritas bermata pencaharian sebagai petani dan salah satu nya kecamatan yang memiliki potensi perkebunan kelapa sawit. Dimana untuk memenuhi kebutuhan sehari - hari mereka mengusahakan berbagai komoditi pertanian yang salah satunya ialah kelapa sawit. Kecamatan Luhak Nan Duo terdiri dari petani plasma dan petani swadaya, dimana petani plasma merupakan perkebunan rakyat yang dalam pengembangannya diintegrasikan kepada PBSN (Perkebunan Besar Swasta Nasional) sedangkan petani swadaya melakukan kegiatan perkebunannya tidak ada sedikit pun kerjasama dengan pihak lain manapun.

Diakui bahwa kontribusi usahatani kelapa sawit telah menjadi sumber pendapatan bagi ratusan ribu petani di Sumatera Barat. Dari focus group discussion terungkap bahwa pendapatan petani dari kelapa sawit saat ini sebesar Rp3,5 juta per bulan (Hasnah, 2016). Nilai ini jauh lebih besar dari pendapatan yang diterima oleh petani pada tahun 2011 yaitu sebesar Rp.1,6 
juta per bulan (Husril , 2011). Namun tingkat pendapatan ini sangat bervariasi. Jika dibandingkan pendapatan dari usahatani kelapa sawit antara petani plasma dan petani swadaya, ternyata keuntungan yang diterima petani kebun plasma lebih besar yaitu Rp 15.455.607,37 per hektar, dibandingkan petani kebun swadaya yang hanya memperoleh $\mathrm{Rp}$ 4.210.600,33 per hektar (Nirtasari, 2010). Hasil penelitian ini perlu dikaji lebih lanjut untuk mengetahui penyebab kesenjangan pendapatan yang terjadi.

Perkebunan kelapa sawit berdasarkan status penguasaanya, sebagian besar dimiliki oleh perkebunan kelapa sawit rakyat. Perkebunan sawit rakyat terbagi menjadi dua, yaitu perkebunan rakyat petani plasma dan perkebunan rakyat petani swadaya. Perkebunan rakyat petani plasma merupakan perkebunan rakyat yang bekerjasama dengan perusahaan kelapa sawit berupa program yang sering disebut Perkebunan Inti Rakyat (PIR). Berbeda dengan petani plasma yang bekerjasama dengan perusahaan, petani swadaya melakukan kegiatan perkebunannya tanpa kerjasama dengan pihak lain manapun.

Penelitian ini dilakukan bertujuan untuk mengetahui profil usaha perkebunan kelapa sawit petani plasma dan petani swadaya dan menganalisis perbandingan pendapatan dan keuntungan usahatani kelapa sawit antara petani plasma dengan petani swadaya di Kecamatan Luhak Nan Duo Kabupaten Pasaman Barat.

\section{METODE PENELITIAN}

\section{Tempat dan Waktu Penelitian}

Penelitian ini dilakukan pada usaha perkebunan kelapa sawit rakyat di Kabupaten Pasaman Barat tepatnya di Kecamatan Luhak Nan Duo. Lokasi ini dipilih karena di Kecamatan Luhak Nan Duo merupakan daerah yang telah melakukakan replanting dan juga merupakan daerah replanting terluas di Kabupaten Pasaman Barat yaitu 1194 hektar. Serta para petani sawit di daerah ini juga sudah menggunakan bibit varietas unggul untuk tanaman kelapa sawitnya. Pe

Metode Penelitian

Metode yang digunakan dalam penelitian adalah metode survey, karena pengambilan data dilakukan melalui wawancara dan pengisian kuisioner.Metode survey adalah penyelidikan yang diadakan untuk memperoleh fakta-fakta dari gejalagejala yang ada dan mencari keteranganketerangan secara faktual, baik tentang institusi sosial, ekonomi dan politik dari suatu kelompok ataupun suatu daerah (Nazir, 2009). Penelitian survey adalah penelitian yang mengambil sampel dari suatu populasi dan menggunakan kuisioner sebagai alat pengumpulan data (Singarimbun dan Effendi, 1989).

\section{Metode Pengumpulan Data}

Data yang dikumpul data penelitian ini adalah data primer dan data sekunder. Data primer diperoleh dari petani sampel melalui wawancara langsung dengan menggunakan kuisioner dan pengamatan langsung di lapangan. Adapun pihak-pihak yang diwawancrai adalah petani sampel, kultur teknis, pemakaian faktor produksi, jumlah produksi, harga jual, sumber modal, bentuk penjualan produksi, hasil produksi dijual kepada siapa, penetapan harga jual dan cara pembayaran.

Data sekunder diperoleh dari studi pustaka, literatur data yang tersedia, melakukan wawancara mendalam dengan pelaku usaha, tokoh lembaga swadaya masyarakat (LSM), lembaga dan instansi terkait dengan objek penelitian yaitu Badan Pusat Statistik Sumatera Barat, Badan Pusat Statistik Kabupaten Pasaman Barat, Dinas Pertanian, Penelitian terdahulu, Proses penelitian ini dimulai dengan penelusuran sumber data dari berbagai referensi yang relevan, dilanjutkan dengan wawancara kepada narasumber yang terkait dengan penelitian. 


\section{Topik Data dan Variabel}

Berdasarkan tujuan penelitian yang pertama topik data yang diteliti sesuai dengan tujuan penelitian adalah:

1. Gambaran profil usaha

2. Identitas petani

3. Kultus teknis dan pasca panen

4. Sumber modal

5. Sumber informasi

6. jumlah produksi

7. harga jual

8. penerimaan dari usahatani

9. biaya dalam usahatani

10. pendapatan dari usahatani

11. keuntungan dari usahatani

\section{Analisis Data}

\section{Analisis Deskriptif}

Analisis deskriptif merupakan analisis yang bertujuan untuk membuat gambaran mengenai situasi dan kejadian (Nazir, 2009). Analisis data yang digunakan untuk tujuan kedua adalah analisis secara kuantitatif yaitu menganalisis perbandingan pendapatan dan keuntungan yang diperoleh petani dari usahatani kelapa sawit petani ekspor plasma dengan petani swadaya.Analisis kuantitatif digunakan dalam menilai kelayakan usahatani melalui tingkat pendapatan, keuntungan, analisa R/C selama satu kali musim tanam.

\section{Analisis Kuantitatif}

Data-data yang diperoleh ditabulasi dan diambil nilai rata-rata masing-masing komponen yang dihitung, kemudian dianalisis secara deskriptif yaitu menggambarakan pengalokasian usahatani dalam berusahatani kelapa sawit dalam satu tahun proses produksi. Perhitungan yang dipakai adalah sebagai berikut:

\section{Penerimaan Petani}

Penerimaan usahatani adalah perkalian antara produksi yang diperoleh dengan harga jual (Soekartawi, 2006: 54). Dapat dirumuskan sebagai berikut:

$$
\text { TRi=Yi . Pyi }
$$

Dimana :

TRi $=$ Total Penerimaan $(\mathrm{Rp} / \mathrm{Ha} / \mathrm{MT})$

$\mathrm{Yi}=$ Jumlah Produksi (kg/Ha/MT)

Pyi $=$ Hargajual $(\mathrm{Rp} / \mathrm{kg})$

\section{Pendapatan Petani}

Pendapatan Usahatani adalah selisih antara penerimaan dan biaya yang dibayarkan. Pendapatan usahatani dapat dirumuskan sebagai berikut:

$$
\mathrm{Pd}=\mathrm{TR}-\mathrm{Bt}
$$

Dimana :

$$
\begin{aligned}
\mathrm{Pd}= & \text { Pendapatan usahatani kelapa sawit } \\
& (\mathrm{Rp} / \mathrm{Ha} / \mathrm{MT}) \\
\mathrm{TR}= & \text { Total Penerimaan }(\mathrm{Rp} / \mathrm{Ha} / \mathrm{MT}) \\
\mathrm{Bt}= & \text { Biaya yang dibayarkan } \\
& (\mathrm{Rp} / \mathrm{Ha} / \mathrm{MT})
\end{aligned}
$$

\section{Keuntungan Petani}

Keuntungan petani atau pendapatan bersih adalah selisih antara penerimaan dengan biaya total. Biaya total adalah seluruh biaya yang digunakan dalam berproduksi, terdiri dari biaya yang dibayarkan dan biaya yang diperhitungan (Soekartawi, 1995).

$$
\mathrm{K}=(\text { Yi.Pyi) }-\mathrm{BT}
$$

Dimana :

$\mathrm{K}$ = Keuntungan dari usahatani dari kelapa sawit (Rp/Ha/MT)

Yi = Jumlah produk kelapa sawit $(\mathrm{Kg} / \mathrm{Ha} / \mathrm{MT})$

Pyi = Harga jual kelapa sawit $(\mathrm{Rp} / \mathrm{Kg})$

$\mathrm{BT}=$ Biaya total $(\mathrm{Rp} / \mathrm{Ha} / \mathrm{MT})$

\section{HASIL DAN PEMBAHASAN}

\section{Gambaran Umum Daerah Penelitian}

Kecamatan Luhak Nan Duo adalah salah satu kecamatan yang terdapat di Kabupaten Pasaman Barat, Provinsi Sumatera Barat. Secara geografis, Kecamatan Luhak nan duo berada pada $00^{\circ} .03 ' 50 " \mathrm{LU}$ (Lintang Utara)-00 $.05^{\circ} .18^{\prime \prime} \mathrm{LS}$ (Lintas Selatan) dan 99'36'50"-99'59'25" 
BT (Bujur Timur). Kecamatan luhak nan duo berada pada ketinggian 0-1.250 mdpl dengan suhu $22,0^{\circ} \mathrm{C}-31,7^{\circ} \mathrm{C}$ dan curah hujan 384,88 $\mathrm{mm} /$ bulan. Luas daerah Kecamatan luhak nan duo 4,04 $\mathrm{km}^{2}$ dari total luas Kecamatan Kuranji yaitu $57,41 \mathrm{~km}^{2}$. Kecamatan Luhak Nan Duo memiliki sebanyak 11 kecamatan, dimana salah satunya adalah Kecamatan Luhak Nan Duo.

\section{Aktivitas Usaha Kelapa Sawit}

Petani sampel yang diambil berjumlah 60 orang secara Purposive Sampling artinya petani tersebut telah memenuhi kriteria petani sampel. Kriteria petani tersebut disesuaikan dengan umur tanaman yang diusahakan yaitu telah mewakilkan umur ekonomis tanaman kelapa sawit yaitu 60 . Identitas petani sampel menggambarkan tentang umur, jenis kelamin, pendidikan, pengalaman berusahatani, pekerjaan dan status lahan dalam perkebunan kelapa sawit plasma dengan kelapa sawit swadaya ini. Untuk lebih jelas dapat dilihat pada Tabel 1.

Tabel 1.

Profil usaha perkebunan kelapa sawit petani plasma dan petani swadaya di Kecamatan Luhak Nan Duo Kabupate Pasaman Barat

\begin{tabular}{|c|c|c|c|c|c|}
\hline \multirow[t]{2}{*}{ No } & \multirow[t]{2}{*}{ Keterangan } & \multicolumn{2}{|c|}{ Petani Plasma } & \multicolumn{2}{|c|}{ Petani Swadaya } \\
\hline & & $\begin{array}{l}\text { Jumlah } \\
\text { (orang) }\end{array}$ & $\begin{array}{c}\text { Persentase } \\
(\%)\end{array}$ & $\begin{array}{l}\text { Jumlah } \\
\text { (Orang) }\end{array}$ & $\begin{array}{c}\text { Persentase } \\
(\%)\end{array}$ \\
\hline 1. & Umur (Tahun) & & & & \\
\hline & $28-81$ & 21 & 70 & 21 & 70 \\
\hline & $>81$ & 9 & 30 & 9 & 70 \\
\hline 2. & Tingkat pendidikan & & & & \\
\hline & Tidak sekolah & 1 & 3.33 & 1 & 3.33 \\
\hline & SD & 6 & 20.00 & 5 & 17.24 \\
\hline & SMP & 8 & 26.67 & 10 & 34.48 \\
\hline & SMA & 13 & 44.83 & 13 & 44.83 \\
\hline & Perguruan tinggi & 2 & 6.09 & 1 & 3.33 \\
\hline 3. & Jumlah tanggungan & & & & \\
\hline & $1-3$ & 23 & 76.67 & 19 & 65.51 \\
\hline & $4-6$ & 7 & 23.33 & 11 & 37.81 \\
\hline 4 & Status kepemilikan lahan & & & & \\
\hline & Milik sendiri & 30 & 100 & 30 & 100 \\
\hline & Bagi hasil & - & - & - & - \\
\hline 5 & Pengalaman berusahatani & & & & \\
\hline & $2-9$ & 3 & 10 & 3 & 10 \\
\hline & $10-19$ & 12 & 40 & 13 & 44.83 \\
\hline & $20-40$ & 15 & 50 & 14 & 50 \\
\hline 6 & Luas lahan (Ha) & & & & \\
\hline & 2 & 30 & 100 & 30 & 100 \\
\hline
\end{tabular}

\section{Petani Plasma Kelapa Sawit}

Identitas petani sampel pada petani plasma meliputi nama petani, umur petani, pendidikan, pengalaman berusahatani, luas lahan, status kepemilkan lahan dan jumlah tanggungan keluarga. Berdasarkan umur sebagian besar petani plasma berada pada usia produktif, yatiu berumur 24-81 tahun sebanyak 70\% sedangkan petani yang berumur $>81$ tahun sebanyak 30\%. hal ini berarti rata-rata petani plasma berada pada kelompok usia produktif untuk melakukan pekerjaan atau menjalankan usahataninya, kemampuan bekerja sesorang sangat dipengaruhi oleh faktor umur.

Umur merupakan salah satu faktor yang dapat mempengaruhi produktifikas 
kerja seseorang. Tingkat umur seseorang akan berpengaruh terhadap kemampuannya dalam mengerjakan pekerjaannya, karena terjadi peningkatan kemampuan fisik seiring dengan meningkatnya umur dan pada umur tertentu akan terjadi penurunan produktivitas.

Usia produktif untuk bekerja adalah umur 24-81tahun. Umur berpengaruh terhadap kemampuan fisik petani dalam mengelola usahataninya maupun usaha pekerjaan tambahan lainnya (Hermaya Rukka, 2003:21). Hal ini sesuai dengan pendapat Swasta dalam Desi (2014) yang menyatakan bahwa tingkat produktivitas kerja seseorang akan mengalami peningkatan sesuai dengan penambahan umur, kemudian akan menurun kembali menjelang usia tua.

Berdasarkan tingkat pendidikan sebanyak $44.83 \%$ petani plasma memiliki pendidikan terakhir SMA dan selanjutnya adalah SMP sebesar $26.67 \%$, pendidikan SD sebanyak $20 \%$ sedangkan yang tidak bersekolah sebanyak $3.33 \%$. dapat dilihat bahwa umumnya tingkat pendidikan petani sampel masih tergolong rendah. Tingkat pendidikan seseorang merupakan suatu indikator yang mencerminkan kemampuan seseorang untuk dapat menyelesaikan suatu jenis pekerjaan atau tanggung jawab. Dengan latar belakang pendidikan seseorang dianggap mampu melaksanakan suatu pekerjaan tertentu atau tanggung jawab yang diberikan kepadanya.

Dalam usaha agribisnis, pendidikan tentunya sangat diharapkan dapat membantu masyarakat dalam upaya peningkatan produksi dan produktifitas pada subagribisnis. Tingkat pendidikan yang memadai tentunya akan berdampak pada kemampuan manajemen usaha agribisnis yang digeluti.

Berdasarkan status kepemilikan lahan secara umum petani plasma yaitu: milik sendiri. Petani yang berusahatani dengan menggunakan lahan milik sendiri sebanyak 100\%. Menurut (Hernanto F. , 1988) petani yang berusahatani dilahan miliknya sendiri memilki kebebasan dalam mengolah tanah tersebut, dapat merencanakan dan menentukan cabang usaha atas tanah tersebut, menggunakan teknologi dan cara budidaya yang paling dikuasai dan disenangi oleh petani, dan dapat menjadikan tanah tersebut sebagai agunan. Sedangkan petani yang berusahatani di tanah orang lain, hanya mempunyai kewenangan untuk menggarap tanah tersebut, tidak mempunyai kewenangan untuk menjual dan menjaminkan tanah tersebut.

Berdasarkan pengalaman dalam berusahatani pada petani plasma sebanyak $10 \%$ petani memiliki pengalaman 2-9 tahun, pengalaman berusahatani 10-19 tahun sebesar $40 \%$, dan pengalaman berusahatani 20-40 sebesar 50\%. Hal ini berarti kebanyakan petani sampel memilki pengalaman berusahatani yaitu antara 20-40 tahun artinya petani sudah lama berusahatani. Selain pendidikan formal dan informal yang dapat mrnambah pengetahuan dan meningkatkan keterampilan, pengalaman berusahatani juga menentukan aktivitas petani, dapat memperhitungkan resiko yang mungkin timbul, juga lebih cakap dan hati-hati dalam mengerjakan usahataninya. Menurut (Hernanto F. , 1988) keterbatasan pendidikan dan pengalaman petani dalam berusahatani, petani akan lemah dalam bersaing, lemah dalam penguasaan faktor produksi terutama modal dan pengelolaan itu sendiri.

Luas lahan petani plasma digolongkan kedalam kelompok sedang. Petani yang memiliki luas lahan 2 Ha sebanyak 100\%. Menurut Hernanto (1989:46), pada dasarnya terdapat empat golongan petani berdasarkan tanahnya: pertama, golongan petani luas ( > $2 \mathrm{Ha})$; Kedua, golongan petani sedang (0.51.0 Ha); Ketiga, Golongan petani sempit (< $0.5 \mathrm{Ha}$ ); dan Keempat, golongan buruh tani tidak bertanah. Luas lahan yang diusahakan menentukan pendapatan, taraf hidup, dan derajat kesejahteraan rumah tangga petani.

\section{Petani Swadaya Kelapa Sawit}

Identitas petani swadaya diambil meliputi nama petani, umur petani, pendidikan, pengalaman berusahatani, luas lahan, status kepemiilkan lahan dan jumlah 
tanggungan keluarga. Berdasarkan umur sebagian besar petani swadaya berumur 2481 tahun sebanyak $70 \%$ sedangkan petani yang berumur diatas $>81$ tahun sebanyak $30 \%$. Hal ini berarti bahwa anggota petani swadaya masih berada pada umur produktif. Menurut Soekartawi dkk (1995) umur dapat berpengaruh terhadap kekuatan fisik dan tingkat adopsi inovasi yang lebih tinggi dibandingkan pada usia yang sudah tidak produktif karena pada umumnya petani yang muda memiliki kemampuan fisik yang lebih kuat dibandingkan dengan petani yang tidak berusia produktif.

Berdasarkan tingkat pendidikan untuk petani swadaya sebanyak $44.83 \%$ petani memiliki pendidikan maksimal SMA, tingkat SMP sebanyak $33.48 \%$, SD sebesar $17.24 \%$ dan S1 (Perguruan Tinggi) sebanyak 3,33\%. Tingkat pendidikan umumnya akan mempengaruhi cara berfikir petani dalam mengelola usahataninya. Petani dengan tingkat pendidikan yang lebih tinggi akan lebih mudah menerima inovasi dibandingkan petani yang memiliki tingkat pendidikan yang lebih rendah (Soekartawi:1995).

Jumlah tanggungan keluarga petani swadaya sebanyak $65.51 \%$ petani yang memiliki jumlah tanggungan 1-3 orang, dan jumlah tanggungan sebanyak 4-6 orang sebanyak $34.48 \%$. Untuk status kepemilikan lahan petani swadaya yaitu: petani yang memiliki lahan sendiri dimana sebanyak $100 \%$.

Berdasarkan pengalaman berusahatani petani swadaya telah memiliki pengalaman berusahatani selama 2-9 tahun sebanyak 10\%, 10-19 tahun sebanyak 40\%, dan pengalaman berusahatani selama 20-40 tahun 50\%. Menurut Soekartawi dkk (1995) pengalaman seseorang dalam berusahatani akan berpengaruh terhadap tingkat keterampilan dalam menjalankan usaha dan kemampuan dalam mengambil keputusan untuk kemajuan usahanya. Luas lahan yang dimiliki petani swadaya sebesar $100 \%$ petani yang memiliki luas lahan $2 \mathrm{Ha}$.

\section{Pendapatan dan Keuntungan Usaha Kelapa Sawit Petani Plasma dan Petani Swadaya}

Keuntungan merupakan selisih antara penerimaan dengan biaya yang dibayarkan dan biaya yang diperhitungkan dalam proses produksi. Rata-rata yang diterima petani plasma per luas lahan adalah Rp 6,412,800.00 atau Rp 15,160,888.89 per hektar. Sedangkan penerimaan petani swadaya adalah sebesar Rp 4,343,172.41 per luas lahan atau Rp 13,000,985.22 per hektar.

Penerimaan dikurangi dengan biaya total yaitu biaya yang dibayarkan dan biaya yang tidak dibayarkan yang terkait langsung maupun tidak langsung dengan usahatani. Berdasarkan Tabel 1 dapat dilihat bahwa biaya total dalam analisis keuntungan merupakan penjumlahan antara biaya yang dibayarkan dan biaya yang diperhitungkan. Sehingga keuntungan dapat diperoleh dari selisih antara penerimaan dengan biaya total dalam usahatani.

Pendapatan usahatani merupakan salah satu cara untuk membandingkan biaya dan penerimaan dari suatu proses produksi. Usahatani dikatakan berhasil apabila penerimaan lebih besar dari biaya dan diakatan merugi apabila penerimaan lebih kecil dari biaya. Analisa pendapatan memberikan bantuan untuk menggambarkan apakah kegiatan usahatani berhasil atau tidak.

Rata-rata keuntungan yang diperoleh petani plasma luas lahan adalah sebesar $\mathrm{Rp}$ 2,386,939.01/MT atau Rp $5,817,310.10 / \mathrm{Ha} / \mathrm{MT}$ sedangkan petani swadaya sebesar Rp 1,522,773.43/Luas Lahan/MT atau Rp 4,706,431.60/Ha/MT. Persentase keuntungan yang diperoleh oleh petani plasma adalah sebesar $61.05 \%$ sedangkan untuk petani swadaya sebesar 38.94\% dari total keuntungan yang diperoleh oleh petani sampel.

Berdasarkan hal diatas dapat dijelaskan bahwa semakin besar penerimaan yang diperoleh oleh petani serta semakin kecil biaya yang dikeluarkan oleh petani maka semakin besar pula keuntungan yang diperoleh, namun apabila semakin kecil 
penerimaan yang diperoleh oleh petani serta semakin besar biaya yang dikelurkan oleh petani maka semakin kecil pula keuntungan yang diperoleh oleh petani tersebut. Besar kecilnya penerimaan dipengaruhi oleh jumlah produksi dan biaya total yang diperoleh oleh petani.

Tabel 2.

Keuntungan usaha kelapa sawit petani plasma dan petani swadaya di Kecamatan Luhak Nan Duo Kabupate Pasaman Barat

\begin{tabular}{llrr}
\hline No. & \multicolumn{1}{c}{ Variabel } & $\begin{array}{c}\text { Petani Plasma } \\
\text { per Hektar }\end{array}$ & $\begin{array}{c}\text { Petani Swadaya } \\
\text { per Hektar }\end{array}$ \\
\hline 1. & Produksi (Kg) & $3,032.18$ & $2,600.20$ \\
2. & Harga (Rp) & $5,000.00$ & $5,000.00$ \\
3. & Penerimaan (Rp) (a) & $15,160,888.89$ & $13,000,985.22$ \\
4. & Biaya yang Dibayarkan (Rp/Ha/MT) (b) & & \\
& 1. Biaya Sawit & $300,000.00$ & $300,000.00$ \\
& 2. Biaya Pupuk & $869,861.11$ & $691,854.68$ \\
& 3. Biaya Pestisida & $99,710.83$ & $84,512.25$ \\
& 4. Biaya TKLK & $2,250,648.26$ & $1,969,875.00$ \\
& 5. Biaya Pajak PBB dan Sewa Lahan & $4,212,493.55$ & $3,710,848.71$ \\
& 6. Sewa Mesin & $265,119.52$ & $267,529.69$ \\
& 7. Biaya Angkut & $236,888.89$ & $236,381.55$ \\
& 8. Bunga Pinjaman/MT & $183,333.33$ & - \\
& Total Biaya Dibayarkan (Rp/Ha/MT) & $8,438,055.49$ & $7,260,637.87$ \\
5. Biaya Diperhitungkan (Rp/Ha/MT) (c) & & \\
& 1. Biaya TKDK & $730,550.35$ & $705,787.60$ \\
& 2. Biaya Penyusutan Alat & $194,883.33$ & $192,897.78$ \\
& 3. Bunga Modal & $33,636.33$ & $133,811.26$ \\
& Total Biaya Diperhitungkan (Rp/Ha/MT) & $959,070.01$ & $1,033,915.74$ \\
\hline 6. & Biaya Total (b+c) =d & $9,397,125.50$ & $8,294,553.62$ \\
\hline 7. & Pendapatan (a-b) & $6,784,036.18$ & $5,740,347.35$ \\
\hline 8. & Keuntungan (a-d) & $5,817,310.10$ & $4,706,341.60$ \\
\hline
\end{tabular}

\section{SIMPULAN}

Rata-rata penerimaan yang diterima petani plasma perluas lahan adalah Rp. 6,412,800.00. Penerimaan petani swadaya adalah sebesar Rp. 13,000,985.22 per hektar. Terdapat perbedaan pendapatan dan keuntungan petani plasma dan swadaya adalah dimana nilai signifikansi yang diperoleh $<0.05(0.001<0.05)$. tersebut berpengaruh terhadap usahatani. Perbedaan pendapatan dan keuntungan terjadi karena jumlah produksi, pendapatan, dan penerimaan yang diperoleh petani plasma lebih besar dibandingkan petani swadaya. Perbedaan antara pendapatan dan keuntungan yang diperoleh karena petani plasma memiliki modal yang tercukupi untuk memnuhi seluruh kebutuhan usahataninya.

Terdapat perbedaan penggunaan pupuk, jumlah produksi, serta struktur biaya petani plasma dan swadaya, dimana $<0.05$ ( $\mathrm{T}$ tabel > $\mathrm{T}$ hitung). Adapaun perbedaan tersebut terletak pada penggunaan pupuk, pemakaian tenaga kerja, jumlah produksi, hal tersebut terjadi karena perbedaan jumlah modal serta teknik budidaya petani kelapa sawit seperti pelaksanaan penyiangan, penanaman, serta pemupukan.

\section{Saran}

Untuk wilayah yang secara sarana dan faktor penunjang dalam penyedia pembiayaan bagi petani dalam pelaksanaan kegiatan usahatani sebaiknya petani yang kekurangan modal melakukan peminjaman pada lembaga keuangan karena lebih menguntungkan bagi petani, dan dapat meningkatkan pendapatan dan keuntungan petani. 
Kepada petani kelapa sawit yang keterbatasan biaya untuk modal ushataani sebaiknya melakukan pinjaman kepada lembaga keuangan, agar petani tidak selalu bergantung pada hasil pendapatan musim lalu serta akan terwujudnya kesejahteraan dalam keluarga petani.

\section{DAFTAR PUSTAKA}

Adiwilaga, 1992. Ilmu Usaha Tani. Cetakan ke-III. Alumni. Bandung.

BPS Sumatra Barat, 2016. Daerah sentral produksi kelapa sawit. Pasaman Barat.

Bagun, 2005. Aspek teknis dan mangemen. Jakarta.

BAPPEDA. 2019. Laporan Tahunan Bidang Ekonomi BAPPEDA. Pasaman Barat.

Dirjen perkebunan, 2016. Sepuluh daerah penanaman sawit terluas di Indonesia. Sumatra Barat.

GAPKI (Gabungan Pengusaha Kelapa Sawit Indonesia). 2019. "Peran Strategis Sawit Rakyat Indonesia". Tersedia pada: gapki.id diakses pada 23 Maret 2019.

Hasnah dkk, 2016. Hasil pendapatan usahatani mampu memenuhi kebutuhan keluarga petani. Universitas Andalas, Sumatera Barat.
Hermaya Rukka. 2003. "Motivasi Petani dalam Menerapkan Usahatani Organik Pdi Sawah". Tesis . Sekolah Tinggi Pasca Sarjana IPB-Bogor.

Hernanto, F. 1988. Ilmu Usahatani. Penebar Swadaya Anggota IKAPI. Jakarta.

Hernanto, 1989. Biaya produksi bagian dari anggaran produksi. Jakarta.

Husril Ridho, 2011. Analisa Usaha Tani Perkebunan Kelapa Sawit Rakyat Swadaya di Kenagarian Kinali Kabupaten Pasaman Barat. Universitas Andalas.

Nazir, Moh. (2009). Metode Penelitian. Jakarta: Ghalia Indonesia.

Singarimbun, M dan S. Effendi (Editor). 1989. Metode Penelitian Survay. LP3S,. Jakarta.

Soekartawi.1995. Analisis Usaha Tani. Universitas Indonesia Press, Jakarta.

Soekartawi. 2006. Analisis Usaha Tani. Universitas Indonesia Press, Jakarta.

Zakaria, W.A. Endaryanto, T. Indah, L.A.M. Sari, I.R.M. dan Mutolib, A (2020) Pendapatan dan Ksejahteraab Rumah Tangga Petani Ubi Kayu di Pprovinsi Lmapung Jurnal Agribisnis Indonesia (Journal of Indonesian Agribusiness), 8 (1). pp. 83-93. 